\title{
Penerapan Adaptive Neuro Fuzzy Inference System Dalam Memprediksi Volume Pemakaian Air Bersih
}

\author{
Niska Ramadani \\ Dosen Universitas Dehasen Bengkulu \\ niskaramadani@gmail.com
}

\begin{abstract}
ABSTRAK
Pertumbuhan penduduk harus disertai dengan ketersediaan air yang sehat dan bersih. Dalam kehidupan sehari-hari apabila air yang diproduksi dari suatu instalasi jauh lebih kecil dari pada jumlah distribusi air yang diberikan kepada pelanggan, maka akan berdampak pada distribusi air secara bergantian. Dari Permasalahan di atas, dibutuhkan sebuah metode untuk memprediksi jumlah pemakaian air, sehingga dapat menjadi pedoman untuk memproduksi jumlah air untuk hari berikutnya. Dalam penelitian ini, menjelaskan bagaimana menentukan prediksi jumlah pemakaian air bersih pada satu instalasi PDAM agar kebutuhan pelanggan dapat terpenuhi. Data yang digunakan sebagai input pada ANFIS adalah data pemakaian (distribusi) air yang kemudian dinormalisasi dan clustering untuk menjadi input pada proses ANFIS yang terdiri atas 5 lapisan dan diimplementasi dengan fungsi keanggotaan Fuzzy yang ada pada Toolbox Matlab sehinga didapatkan prediksi untuk setiap instalasi.
\end{abstract}

Kata Kunci: ANFIS, Prediksi pemakaian air bersih, Matlab

\section{PENDAHULUAN}

Sebagai pusat kehidupan penduduk, suatu perkotaan dengan berbagai sarana pelayanannya sangat memerlukan persediaan air bersih. Pertumbuhan penduduk harus disertai dengan ketersediaan air yang sehat dan bersih. Tetapi permasalahan pada distribusi air akan timbul apabila air yang diproduksi dari suatu instalasi jauh lebih kecil dari pada jumlah distribusi air yang diberikan kepada pelanggan, dan hal ini yang akan menyebabkan krisis air bersih yang akan berdampak pada penyaluran air secara bergantian. Sementara itu, hampir diseluruh bidang kehidupan manusia pada saat ini memanfaatkan kemajuan teknologi. Salah satu kemajuan teknologi tersebut adalah jaringan syaraf tiruan. Untuk mengatasi masalah diatas, dalam memprediksi jumlah pemakaian air bisa diterapkan dengan menggunakan metode Adaptive Neuro Fuzzy Inferrence System (ANFIS) dengan menggunakan sampel data jumlah distribusi air bersih. Alat

190 Diterbitkan Oleh Program Studi Pendidikan Informatika STKIP PGRI Sumbar 
bantu yang digunakan untuk melakukan prediksi adalah toolbox logika fuzzy yang terdapat pada software Matlab.

Tujuan Penelitian

Tujuan dari penelitian ini adalah sebagai berikut:

1. Menganalisis data-data yang telah diperoleh dari pihak PDAM Tirta Sakti Kota Sungai Penuh dan mengolahnya dengan metode ANFIS

2. Membandingkan keakuratan hasil pengolahan data yang dikerjakan secara manual dan yang dikerjakan pada aplikasi pemrograman Matlab, dengan menggunakan data-data yang telah diperoleh dari PDAM Tirta Sakti Kota Sungai Penuh.

\section{Rumusan Masalah}

Berdasarkan latar belakang di atas dapat dirumuskan masalah-masalah sebagai berikut :

1. Bagaimana bentuk model prediksi untuk menentukan kriteria volume pemakaian air bersih?

2. Bagaimana menerapkan metode Adaptive Neuro Fuzzy Inferrence System (ANFIS) pada prediksi pemakaian air bersih?

3. Bagaimana hasil prediksi pemakaian air bersih dengan metode ANFIS dapat digunakan sebagai acuan dalam memproduksi air bersih?

\section{LANDASAN TEORI}

\section{Jaringan Syaraf Tiruan}

Secara umum jaringan saraf terbentuk dari jutaan struktur dasar neuron yang menjadi dasar dalam pengoperasian jaringan syaraf tiruan (Siang, 2009). Jaringan saraf tiruan dianggap sebagai salah satu metode matematika dan komputasi modern yang digunakan untuk memecahkan masalah yang dinamis.(Reza Khaze et al. 2013).

Neuro-fuzzy adalah gabungan dari dua sistem yaitu sistem logika fuzzy dan jaringan syaraf tiruan. Sistem neurofuzzy berdasar pada sistem inferensi fuzzy yang dilatih menggunakan algoritma pembelajaran yang diturunkan dari sistem jaringan syaraf tiruan. (Boy Fechera 2012).

Dengan demikian, sistem neurofuzzy memiliki semua kelebihan yang dimiliki oleh sistem inferensi fuzzy dan sistem jaringan syaraf tiruan. Dari kemampuannya untuk belajar maka sistem neuro-fuzzy sering disebut sebagai ANFIS (Adaptive Neuro Fuzzy Inference Systems).(Arfiansyah Rahman 2012)

\section{ANFIS (Adaptive Neuro Fuzzy Inference System) \\ ANFIS merupakan suatu teknik optimasi yang menggabungkan Neural Network dan Fuzzy Logic. Neural}


Network mengenal pola dan bell dengan nilai maksimum 1 dan menyesuaikan dengan perubahan pola. (Jangid 2011)

\section{Sedangkan Fuzzy Logic} menggabungkan pengetahuan manusia dan menarik kesimpulan untuk membuat suatu keputusan.(Septiadi 2008).

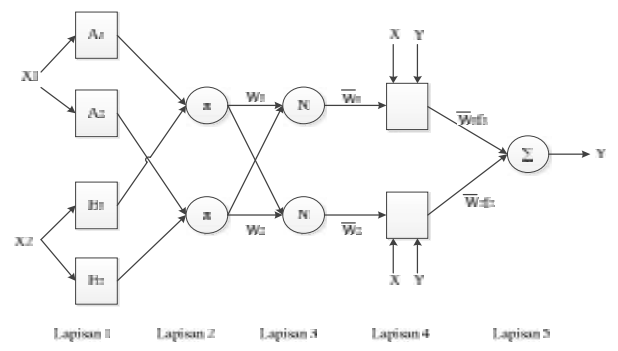

Gambar 1 : Struktur Jaringan ANFIS

Pada gambar struktur ANFIS, struktur tersebut terdiri dari 5 lapisan, 2 masukan $\left(X_{1}\right.$ dan $\left.X_{2}\right)$ dan 1 keluaran $(Y)$. Penjelasan pada masing-masing lapisan struktur ANFIS dapat dijabarkan sebagai berikut:

\section{a) Lapisan 1}

Setiap simpul $i$ pada lapisan ini adalah simpul adaptif dengan fungsi simpul: $O 1, i=\mu A i(x) \quad$ untuk $i=1,2$ atau $\quad O 1, i=\mu A i-2(y) \quad$ untuk $i=3,4$ .Di mana: Dengan $X$ dan $Y$ adalah input pada simpul ke $\underline{i}$, dan $A_{i}$ adalah label linguistik seperti baik, buruk, dsb. Dengan kata lain $O_{1, i}$ adalah fungsi keanggotaan dari $A_{i}$ dan menspesifikasikan derajat keanggotaan $X$ dan $Y$ terhadap $A_{i}$. Fungsi keanggotaan $\mu A_{i}(x)$ didasarkan pada persamaan nilai minimum 0. Fungsi keanggotaan parameter dari $A$ dapat didekati dengan fungsi bell:

$$
\mu_{A_{1}} X=\frac{1}{1+\frac{x-c_{i}}{a_{i}}{ }^{b_{i}}}
$$

Di mana:

$\{a i, \quad b i, c i\}$ : Himpunan parameter. $\mu(\mathrm{x}) \quad$ : Derajat Keanggotaan

b. Lapisan 2

Setiap simpul pada lapisan ini adalah simpul nonadaptif. Outputnya merupakan perkalian dari semua input yang masuk pada lapisan ini $O_{2, i}=w i=\mu A_{i}(x) \cdot \mu A_{i-2}(y), \quad i=$ $1,2, \ldots, n$ Tiap keluaran simpul menyatakan derajat pengaktifan (firing strength) tiap aturan fuzzy. Banyaknya simpul pada lapisan ini menunjukkan banyaknya aturan yang dibentuk.

c. Lapisan 3

Untuk node yang terdapat pada layer ke-3, dan memiliki label $N$. Label $N$ mengsidentifikasikan dilakukannya normalisasi terhadap output dari layer ke-2. output dari layer ini adalah :

$O_{3, i}=\bar{w}=\frac{w_{i}}{w_{i}+w_{2}}, i=1,2$

Apabila dibentuk lebih dari 2 aturan, fungsi dapat diperluas dengan membagi

$\bar{w}_{i}$ dengan jumlah total $W$ untuk semua aturan.

d. Lapisan 4 
simpul adaptif dengan fungsi simpul :

$O_{4, i}=\overline{w_{i}} f_{i}=\overline{w_{i}}\left(p_{i} x+q_{i} y+r_{i}\right.$ dengan $\mathrm{W}_{\mathrm{i}}$ adalah bobot yang dinormalkan dari lapisan 3 dan $\{p i, \quad q i, \quad r i\}$ menyatakan parameter konsekuen yang adaptif.

e. Lapisan 5

Fungsi lapisan ini adalah untuk menjumlahkan semua masukan. Fungsi simpul :

$O_{5, i}=\sum \bar{w}_{i} f_{i}=\frac{\sum w_{i} f_{i}}{\sum w_{i}}$

Jaringan adaptif dengan lima lapisan diatas ekivalen dengan sistem inferensi fuzzy Takagi-Sugeno-Kang ( TSK ) atau yang lebih dikenal dengan sugeno.(Syahputra 2012)

\section{Metodologi Penelitian}

Pada tahap metodologi penelitian akan diuraikan tentang metode yang dipakai dalam penelitian yang tercakup dalam kerangka kerja penelitian mulai dari mengidentifikasai masalah, menganalisa masalah, menentukan tujuan, mempelajari literatur dan tutorial, teknik pengumpulan data, menganalisa data, teknik pengujian sistem sampai pada menarik kesimpulan.

\section{ANALISA DAN PERANCANGAN}

Pada tahap analisa data juga akan dijelaskan analisa penyelesaian permasalahan, dengan melakukan normalisasi dan clustering data pemakaian air bersih untuk di analisis ke model prediksi volume pemakaian air bersih dengan menggunakan Adaptive Neuro Fuzzy Inference System (ANFIS).

\section{Analisis Perkiraan Pemakaian Air Bersih.}

Dengan memprediksi volume pemakaian air bersih dengan menggunakan metode Adaptive Neuro Fuzzy Inference System (ANFIS) ini, analisis data didasarkan pada data yang didapatkan dari PDAM Tirta Sakti, yaitu memprediksi jumlah distribusi air bersih dalam waktu satu hari berdasarkan instalasi. Prediksi pemakaian dilakukan dengan mengumpulkan data-data distribusi air bersih pada PDAM pada hari minggu selama 7 minggu mulai dari tanggal 22 Juni - 24 Agustus 2014 yang digunakan sebagai sampel data pada penelitian ini. Data tersebut dinormalisasikan, dan di bagi menjadi 2 input 1 output.

\section{Analisis Metode Adaptive Neuro Fuzzy Inference System (ANFIS)}

Setelah membagi data menjadi 2 input dan 1 output berdasarkan hasil data setelah normalisasi, kemudian kita memasukkan nilai pemakaian air bersih berdasarkan data awal sebelum dinormalisasi sesuai dengan tabel pembagian data. 
Tabel 1 : Data Air Dengan 2 Input dan Satu Output

\begin{tabular}{|c|c|c|c|}
\hline \multirow{2}{*}{ Data } & \multicolumn{2}{|c|}{ Input } & \multirow{2}{*}{ Output } \\
\cline { 2 - 3 } Ke - & $\mathbf{X}_{\mathbf{1}}$ & $\mathbf{X}_{\mathbf{2}}$ & $\mathbf{Y}(\mathbf{t})$ \\
\hline 1 & 60,53 & 62,98 & 64,00 \\
\hline 2 & 62,98 & 64,00 & 64,70 \\
\hline 3 & 64,00 & 64,70 & 65,00 \\
\hline 4 & 64,70 & 65,00 & 65,09 \\
\hline 5 & 65,00 & 65,09 & 66,82 \\
\hline 6 & 65,09 & 66,82 & 67,20 \\
\hline 7 & 66,82 & 67,20 & 67,35 \\
\hline 8 & 67,20 & 67,35 & 73,32 \\
\hline
\end{tabular}

\section{Proses Pengolahan Anfis}

\section{Lapisan 1}

Dengan menghitung nilai untuk setiap neuron pada lapisan pertama, yaitu nilai derajat keanggotaan $A_{1}, A_{2}, B_{1}$, dan $B_{2}$, dengan menggunakan persamaan bell.

$$
\begin{aligned}
\mu A_{1}=\frac{1}{1+{\frac{x_{1}-c_{11}}{a_{11}}}^{2}}=\frac{1}{1+\frac{60,53-65,11}{1,3754}}{ }^{2} \\
=\frac{1}{1+\frac{-4,5829}{1,3754}^{2}}=\frac{1}{124.2682} \\
=0,00805
\end{aligned}
$$$$
\mu B_{1}=\frac{1}{1+\frac{x_{2}-c_{12}{ }^{2}}{a_{12}}}=\frac{1}{1+\frac{62,98-60,53}{0}{ }^{2}}=
$$

1Lapisan Ke dua

Untuk menghitung output lapisan kedua yang disimbolkan dengan karakter phi $(\pi)$. Dengan keluaran pada lapisan ke-2 adalah hasil kali derajat keanggotaan dari lapisan pertama, maka diperoleh perhitungan untuk lapisan ke-2 pada data ke-1

$$
\mathrm{w}_{1}=\mathrm{A} 1^{*} \mathrm{~B} 1=0,0080 * 1=
$$

0,0080

$$
\mathrm{w}_{2}=\mathrm{A}_{2} *{ }_{\mathrm{B} 2}=0,0055 * 1=
$$
0,0055

Untuk menghitung nilai lapisan ketiga yaitu menentukan nilai parameter yang disimbolkan dengan huruf $\mathrm{N}$ yang berarti normalisasi, output lapisan ketiga ini dikenal dengan istilah normalised firing strength maka keluaran dari lapisan ke-3 ( $\hat{w})$ adalah hasil bagi antara nilai $w$ lapisan ke-2 dengan penjumlahan $w_{1}$ dan $w_{2}$. Maka didapatkan hasil untuk perhitungan lapisan ke tiga pada data ke -1 adalah sebagai berikut :

$\widehat{w}_{1}=\frac{w_{1}}{w_{1}+w_{2}}=\frac{0,0080}{0,0080+0,0055}=0,5924$

$\widehat{w}_{2}=\frac{w_{2}}{w_{1}+w_{2}}=\frac{0,0055}{0,0080+0,0055}=0,4184$

Menentukan koefisien parameter pada lapisan ke tiga, merupakan normalisasi output lapisan ke dua. Maka didapatkan hasil perhitungan untuk data ke-1

$p_{1}=\hat{w}_{1} * x_{1}=0,5924 * 60,53=35,86$

$q_{1}=\hat{w}_{1} * x_{2}=0,5924 * 62,98=37,31$

$r_{1}=\hat{w}_{1}=0,5924$

$p_{2}=\hat{w}_{2} * x_{1}=0,4076 * 60,53=24,67$

$q_{2}=\hat{w}_{2} * x_{2}=0,4076 * 62,98=25,67$

$r_{2}=\hat{w}_{2}=0,4067$

Selanjutnya adalah untuk perhitungan output lapisan ke empat yang merupakan consequent parameter. Nilai $X_{1}$ dan $X_{2}$ digunakan dalam perhitungan karena lapisan keempat bersifat 
adaptif. Maka diperoleh perhitungan untuk data ke-1 Lapisan 4 :

$\hat{w}_{1} y_{1}=\left(\hat{w}_{1} x_{1}\right) p_{1}+\left(\hat{w}_{1} x_{2}\right) q_{1}+r_{1}$ $\hat{\mathrm{w}}_{1} \mathrm{y}_{1}=((0,5924 * 60,53) * 35,86)+$ $((0,5924 * 62,98)$

$$
* 37,31)+0,5924
$$

$\hat{\mathrm{w}}_{1} \mathrm{y}_{1}=2.678,6269$

$\hat{w}_{2} y_{2}=\left(\hat{w}_{2} x_{1}\right) p_{2}+\left(\hat{w}_{2} x_{2}\right) q_{2}+r_{2}$

$\hat{\mathrm{w}}_{2} \mathrm{y}_{2}=((0,4076 * 60,53) * 24,67)+$ $((0,4076 * 62,98) * 25,67)+0,4076$

$\hat{\mathrm{w}}_{2} \mathrm{y}_{2}=1.267,9249$

Lapisan Ke lima

Pada Lapisan Kelima merupakan hasil penjumlahan dari output dari lapisan keempat sehingga simbol yang digunakan adalah sigma $(\Sigma)$. Dengan fungsi sebagai berikut : $O_{5, i}=\sum \bar{w}_{i} f_{i}=$ $\frac{\sum w_{i} f_{i}}{\sum w_{i}}$

Maka diperoleh Perhitungan untuk data ke-1 lapisan ke lima adalah sebagai berikut:

$y^{\prime}=\Sigma \hat{w}_{i} y_{i}=\hat{w}_{1} y_{1}+\hat{w}_{2} y_{2}$

$\mathrm{y}^{\prime}=\Sigma \hat{\mathrm{w}}_{\mathrm{i}} \mathrm{y}_{\mathrm{i}}=2.678,6269+1.267,9249=$ $3.946,5518$

Setelah proses perhitungan ANFIS selesai dicari sampai pada nilai output dari lapisan ke-4 dan ke-5, selanjutnya adalah melakukan proses prediksi pemakaian air. Berikut ini adalah proses perhitungan untuk prediksi pemakaian. Data prediksi Pemakaian data ke-i $=\Sigma \hat{w}_{i} y_{i} / x_{2}$

\section{Hasil Prediksi}

Dari hasil output tersebut langkah selanjutnya adalah mengurutkan nilai dari ke enam hasil prediksi mulai dari nilai terkecil sampai pada nilai terbesar. Sehingga nilai yang menjadi data prediksi pemakaian air bersih untuk hari berikutnya adalah dengan nilai terkecil yaitu 62,6636 L/D. Dengan nilai prediksi untuk pemakaian air bersih pada hari berikutnya adalah Maksimal Pemakaian adalah 68,9638 L/D dan minimal pemakaiannya adalah 61,186068 L/D untuk instalasi Sungai Pendung 3.

\section{Implementasi}

Dalam pembuatan Adaptive Neuro Fuzzy Inferrence System (ANFIS) pada Matlab. Data yang dijadikan training adalah gabungan antara input dan output yang dibuat dalam bentuk matrik dengan jumlah 3 kolom (2 input dan 1 output). Setelah menginputkan data, langkah selanjutnya membuat Fuzzy Inferrence System (FIS) pada tab Generate Fis kita pilih Tipe Grid Partition, kemudian Klik Generate Fis, untuk membuat fungsi keanggotaan pada ANFIS.

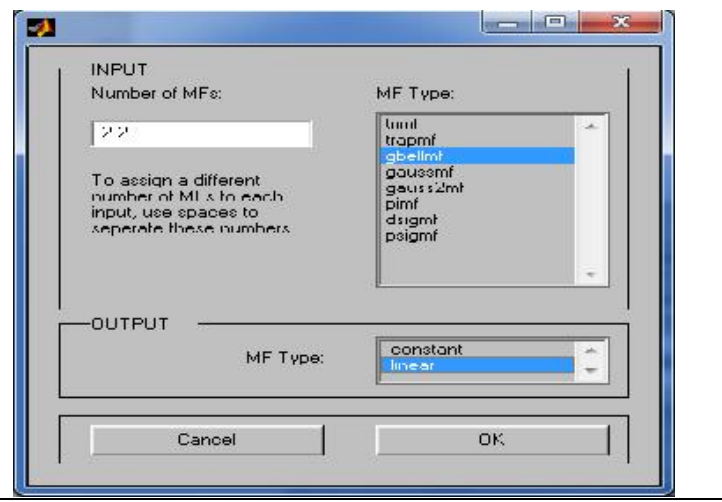


Gambar 2 :Tampilan Untuk Mengenerate FIS

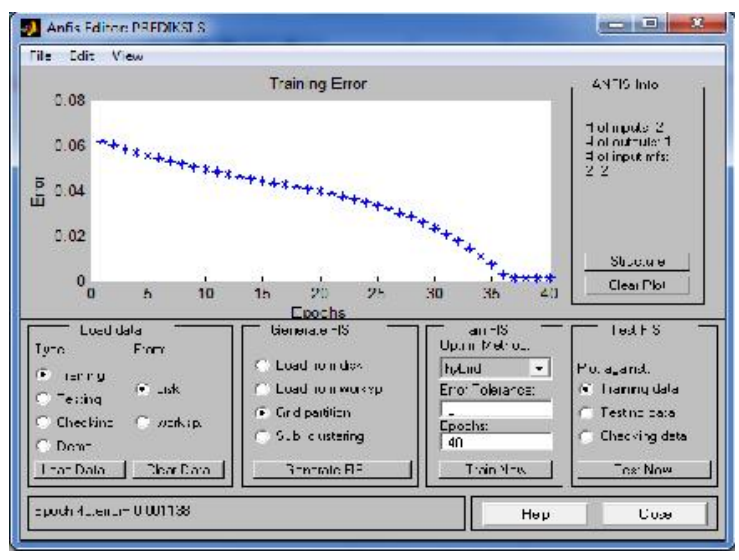

Gambar 3 : Tampilan Hasil Training Output

Jika diperhatikan pada gambar

5.12 dari hasil training data mencapai titik error tetap pada angka 0,001138 pada saat epoch mencapai 40. Dengan nilai error yang kecil maka struktur ANFIS untuk memprediksi pemakaian air bersih dengan 1 output linier dapat digunakan sebagai arsitektur untuk melakukan proses prediksi pemakaian air. Pada tahap ini dimaksudkan untuk mendapatkan hasil dari nilai fuzzy, setelah diadakannya proses Training.

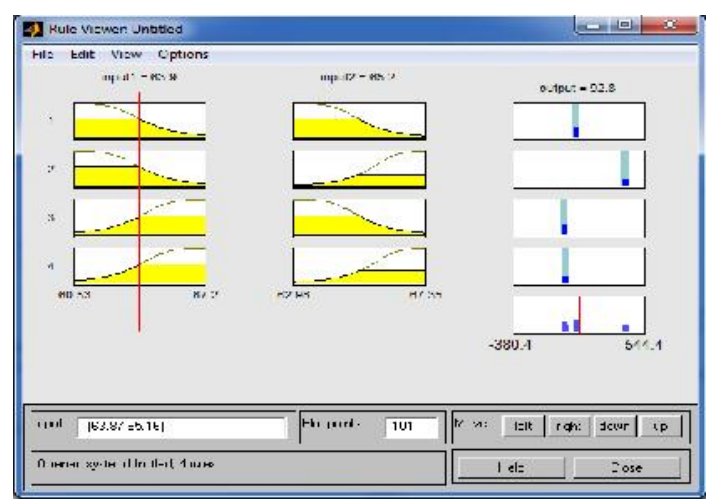

Gambar 4: Tampilan Rule Setelah

\section{Training}

Kemudian kita inputkan data pemakaian air pada kolom input, kemudian tekan enter, maka hasil prediksi berupa output pemakaian air bersih akan kita peroleh

\section{KESIMPULAN}

Dari hasil penelitian dan pengolahan data, serta hasil yang didapatkan. Maka penulisan tesis dapat disimpulkan beberapa hal sebagai berikut :

1. Dalam memprediksi jumlah pemakaian air bersih pada PDAM Tirta Sakti Sungai penuh, data dianalisis dengan memodelkan prediksi dari data sitribusi air pada setiap instalasi sebagai nilai input yang kemudian dinormalisasikan sebagai nilai input dan output, untuk perhitungan ANFIS.

2. Dengan metode ANFIS untuk memprediksi volume pemakaian air bersih dilakukan dengan proses perhitungan ANFIS, dengan mengcluster kan data terlebih dahulu, kemudian mencari nilai rata-rata, standar deviasi, Fungsi Keanggotaan, nilai paramater, sampai menghasilkan jumlah output yang dijadikan sebagai data untuk nilai prediksi pemakaian air hari berikutnya.

3. Dari hasil perhitungan output dengan metode ANFIS, dapat dijadikan pedoman untuk menentukan jumlah

196 Diterbitkan Oleh Program Studi Pendidikan Informatika STKIP PGRI Sumbar 
produksi air untuk hari berikutnya, dengan mengambil nilai terkecil untuk memprediksi jumlah pemakaian terkecil dan maksimal pemakaian dari nilai terbesar pada total output dari lapisan ke 5 pada struktur ANFIS.

\section{DAFTAR PUSTAKA}

Arfiansyah Rahman, A. G. A., Dadang Lukman Hakim. 2012. Prakiraan Beban Puncak Jangka Panjang Pada Sistem Kelistrikan Indonesia Menggunakan Algoritma Adaptive Neuro Fuzzy Inference System. ELECTRANS VOL.11, NO.2.

Boy Fechera, J. K., Siscka Elvyanti 2012. Optimasi Penggunaan Membership Function Logika Fuzzy Pada Kasus Identifikasi Kualitas Minyak Transformator. ELECTRANS Vol.11, No.2.

Jangid, D. C. S. B. a. A. 2011. Discharge Modelling using Adaptive Neuro - Fuzzy Inference System.

Reza Khaze, S., M. Masdari, and S. Hojjatkhah. 2013. Application of Artificial Neural Networks in Estimating Participation in Elections. International Journal of Information Technology, Modeling and Computing 1 (3):23-31.
Computing Pada Prediksi Curah Hujan Di Kalimantan. Meteorologi Dan Geofisika Vol.9 No. 1.

Syahputra, S. d. R. 2012. Prakiraan Beban Listrik Jangka Pendek Kota Banda Aceh Berbasis Logika Fuzzy. Rekayasa Elektrika Vol. 10 No.1.

Septiadi, D. 2008. Aplikasi Soft 